\title{
A.I.D.S.: A THEOLOGICAL AND PASTORAL RESPONSE
}

\author{
G.G. Miller \\ Department of Systematic Theology \\ University of Fort Hare
}

\begin{abstract}
The anticipated A.I.D.S. crisis in Southem Africa presents an opportunity for the Christian chunch to respond positively rather than merely to react negatively. This requires both a theological understanding and a pastoral response. Theologically, A.I.D.S. moy be seen as an object lesson in the interrelation of natural, personal and historical evil. Although both the Old Testament and the New Testament wam against a simplistic doctrine of individual retribution, there are also several differen ways in wich the A.I.D.S. crisis may indeed in some paricular cases be seen as a judge. ment of God while in other cases it is rather a horrifying event. Other relevant issues include matters relating to justification and sanctification and the wider ethical issues of discrimination and human rights, of "public" and "private" morality. The Church's pastoral response should include both "corrective" education to remove irrational and fearful ignorance and also "preventative" education to encourage a monogamous lifestyle. Pastoral ministy must be "redemptive", appropriate to the varying needs of persons with A.I.D.S., of their families and friends and of professional care-providers. The Church cannot ignore the A.I.D.S. crisis, but must respond to it both Biblically and pastorally.
\end{abstract}

\section{INTRODUCTION}

The Christian church has sometimes been criticised for being the last to respond to developments in society, for merely reacting rather than taking the lead in some of the pressing needs of the day. The anticipated A.I.D.S. crisis in Southern Africa may hopefully be one area where there is still an opportunity for the churches to respond timeously and positively, drawing on the costly experience of others in this issue which is only now really making its impact felt locally.

Our churches cannot avoid but must rather face up to the particular Biblical, theological and ethical questions raised, since "as the number of people with A.I.D.S. grows, it will become increasingly unlikely that individual congregations throughout the nation will remain untouched" (Shelp, et al., 1986:179). A.I.D.S. cannot, on the one hand, be naively described as a "homosexual disease"; neither can it be irresponsibly dismissed as a "medical not a moral problem" on the other. The question should be considered on two different but related levels: (1) Biblical - theological and (2) pastoral ministry. 


\subsection{Biblical and Theological Considerations}

\subsubsection{Three types of evil}

A.I.D.S. may be seen as an illustration of the interpenetration of different categories of evil - natural, personal and historical (Shoemaker, 1986:24f). Natural evil concerns destructive forces in the physical universe and asks such questions as: why are there floods, famines, earthquakes and poisonous snakes? Why are there diseases like cancer and A.I.D.S.? Scripture indicates that not only humanity but also nature has been disrupted by the Fall (Gen. 3:17-18; Isaiah 11:6-9; Rom. 8:18-23). Some of this natural evil can also be aggravated by human abuse, e.g. pollution of the environment, misuse of resources and poor hygiene can further increase the spread of famine and disease. It is generally believed that the A.I.D.S. virus was first transmitted to humans through bites from the African green monkey. The virus is harmless in green monkeys, but has become an evil through its transmission to the human race.

Personal evil concerns the irresponsible, malicious or culpable activity of people as acknowledged by the apostle Paul: "For what I do is not the good I want to do; no, the evil I do not want to do - this I keep on doing" (Rom. 7:19). Instead of being isolated, A.I.D.S. has been spread by promiscuous sexual behaviour, primarily by homosexual and bisexual men in "Pattern One" countries (North America, Australia, New Zealand, some areas of South America and most industrialized countries of Western Europe) but also by heterosexuals in general and prostitutes in particular, especially in "Pattern Two" countries (Central Africa and the Caribbean) while the disease has also been spread by intravenous drug abuses (Caraël, 1988:16,17).

Without these complicating factors, the disease would not have spread so rapidly. Thus the natural evil of a virus contracted by a monkey bite has been vastly increased through the personal evil of irresponsible and promiscuous behaviour.

Historical evil is seen where the innocent suffer because of the sins of others or because of evil imbedded in social structures and customs as suggested in "the fathers have eaten sour grapes, and the children's teeth are set on edge" (Ezek. 13:29). Thus, today, about a decade after A.I.D.S. was first diagnosed amongst homosexual men in Los Angeles and New York (Shoemaker, 1986:24; Koop, 1985:25), many innocent people are becoming infected, e.g. non-promiscuous spouses whose partners once had multiple relationships and now unwittingly carry the dreaded virus. (One of the great dangers of A.I.D.S. is that carriers of the virus may not know they have been infected until years later.) Some have even contracted it from blood transfusions (prior to strict testing of blood products from 1985 onwards) while most tragic of all are cases where babies were infected while still in their mother's uterus. A.I.D.S. is thus a vivid 
illustration of the interrelation of natural, personal and historical evil.

\subsubsection{God's judgement}

In what ways may the A.I.D.S. crisis be seen as evidence of the activity of God? Jerry Falwell and Charles Stanley, spokesmen for the "Moral Majority" in the United States, have called A.I.D.S. God's punishment of homosexuals (Shelp et al., 1986:8-9); Shoemaker, 1986:25). In contrast, Episcopal Bishop Paul Moore of New York has insisted that "A.I.D.S. is not God's punishment" (Hancock, 1985:257).

To be able to say with certainty, however, that God either does or doesn't cause A.I.D.S. would need a direct revelation from God. What can we legitimately glean from Scripture here? Is A.I.D.S. a manifestation of the judgment and wrath of God suggested in Romans 1:24-32? My answer is both yes and no.

No, because to claim a direct link between sickness and sin is to ignore the clear teaching of John 9:1-3 and the message of the Book of Job with its rebuke of Job's friends and their doctrine of individual or direct retribution. Jesus also taught that God gives the sunshine and rain to the evil and the good, the just and unjust (Mat. $5: 45$ ). The very fact that both the innocent and the guilty, both "gay" and "straight" have contracted A.I.D.S. must lead us to conclude that the disease is not specially or directly God's judgement on homosexuals.

Romans 1:18-32 does, however, suggest that the wrath of God can result in God "giving us up" to the consequences of our behaviour. Three times Paul agrees "God gave them up" - to "sexual impurity" (v. 24-25 N.I.V.) probably referring to heterosexual promiscuity; God gave them up - "to shameful lusts" (v. 26-27 N.I.V.) and homosexual promiscuity; God gave them up "to improper conduct" (V. 28-32 N.I.V.) such as greed, envy, deceit, gossip, hating God and disobeying parents. Cranfield (1975:121) comments further "that this delivering them up was a deliberate act of judgement and mercy on the part of the God who smites in order to heal (Isaiah 19:22), and that throughout the time of their God-forsakenness God is still concerned with them and dealing with them".

Thus - yes, A.I.D.S. is an example of judgement, but not directly on homosexuals as such; it is judgement on promiscuous behaviour of all kinds, whether homosexual or heterosexual or drug abuse. Yet even here it is only a judgment in particular cases - in some other cases an innocent person suffers; here A.I.D.S. is not a judgement but a tragedy. 
Another possible aspect of God's judgement that is generally overlooked is that suggested by Paul in Romans 2:1 when he turns to the self-righteous who "have no excuse, you who pass judgement on someone else for at whatever point you judge the other, you are condemning yourself because you who pass judgement do the same thing". Shoemaker (1986:26) comments: "We may ourselves experience judgement because of our judgemental attitudes towards those on the margins of our communities". It seems that since for several years A.I.D.S. was regarded only as a "gay disease" which also killed Haitians and drug addicts, very little public funding was allocated to A.I.D.S. research. The "straight" community failed to recognise the solidarity of the fallen human race, that all people are vulnerable, and that what hurts one hurts all and that therefore all need care. If adequate attention had been given to A.I.D.S. in the early years of its development, thousands of lives might have been spared. However, what may have started as a largely "gay" disease has now become a human disease affecting both the moral and the promiscuous, both the homosexual and the heterosexual, both the "innocent" and the "guilty". It was only after the famous Hollywood actor Rock Hudson died of A.I.D.S. that the public began to demand appropriate funding for A.I.D.S. research. In similar vein, one A.I.D.S. sufferer expressed his impression in this way: "Had A.I.D.S. first appeared in heterosexual, Republican, white bankers ... the media would have designed their coverage to evoke a sympathetic rather than a fearful public response" (Shelp et al., 1986:49). Here especially is a lesson which South Africans in general and Christians in particular can apply in responding to the A.I.D.S. crisis.

\subsubsection{Justification and sanctification}

Lutheran Pastor R.L. Schaper (1988:25) believes the A.I.D.S. crisis raises fundamental theological issues such as "do we really believe that justification precedes sanctification? Do we really believe that we are justified by grace through faith rather than by works?" This was because some congregations as a whole or some members of congregations were unwilling to accept believing A.I.D.S. sufferers into the fellowship of the church because of their homosexual orientation. A fellow pastor, reading that a person with A.I.D.S. (hereafter P.W.A.) had been baptized, wrote to the bishop asking for an investigation, insisting that the P.W.A. should have been made to repent of his homosexuality before baptism.

Two consecutive chapters in 1 Corinthians are relevant here: 1 Corinthians 6:9-11 (N.I.V.) lists "homosexual offenders" along with the greedy and shameless as amongst those who "will not inherit the kingdom of God". Paul goes on, however, to emphasize "and that is what some of you were. But you were washed, you were sanctified, you were justified in the name of the Lord Jesus Christ and by the Spirit of our God". 
Clearly, homosexuality is not to be identified with the "unpardonable sin" referred to by Jesus in the gospels. Justification by grace through faith is the one means of forgiveness and acceptance by God and the condition of entry into the body of Christ for all kinds of sinners, heterosexual and homosexual alike.

The same apostle Paul who in 1 Corinthians 4:3-5 warns those who judge prematurely and imagine they are the final judges, also makes it clear in 1 Corinthians 5:9-13 that Christians are indeed to judge the conduct of "insiders" - brothers and sisters in Christ. Proper church discipline is to be maintained. Lutheran R.W. Quere (1987:365), professor of Historical Theology at Wartburg Theological Seminary, responds by maintaining that: "the Church's evangelistic task does not mean 'full acceptance' of the homosexual person or his behaviour ... we must beware of the cheap grace that justifies sin as well as sinners". The church must not confuse justification and sanctification, law and gospel, as Paul explains in Romans 6:1-4 where after his unequivocal exposition of justification by faith alone in Romans 3-5, he asks "what shall we say then? Shall we go on sinning so that grace may increase? By no means! We died to sin, how can we live in it any longer?"

\subsubsection{Related ethical and legal issues: discrimination and human rights}

A.I.D.S. has somtimes been called the "leprosy of the twentieth century". Lepers in the New Testament were clearly a "marginalized" group who did not enjoy the normal rights and privileges of the rest of society. A.I.D.S. sufferers in the United States have been the victims of discrimination in the following ways:

- Employment: Some P.W.A.'s have been overlooked for promotion and salary increases even though their standard of work is above reproach (Shelp et al., 1986:103) while others have been barred from entering buildings housing their former offices.

- Insurance and medical aid: Some insurance companies have refused to cover P.W.A.'s since they are regarded as being "as good as dead". Since March 1989 some of the major South African insurance companies have held special conferences to consider the implications of A.I.D.S. and have warned that A.I.D.S. cover will require greatly increased contributions from both employers and employees (Wakefield, 1989).

- Hospitalization: P.W.A.'s have somtimes been "illegally discharged" from hospital with absolutely no place to go because there, was "no prescribed medical treatment plan" (Hannock, 1985:255). 
- Education: Children diagnosed as having A.I.D.S. have sometimes been barred from schools. In schools where they have been allowed to continue attending classes, other concerned parents have sometimes staged protests or withdrawn their children from these schools (Shelp et al., 1986:2-3).

- A.I.D.S. research: In the early 1980's, the "Moral Majority" group in the United States lobbied against government-funded research to find a cure for A.I.D.S., arguing that homosexuals should solve their own problems (Frame, 1985:50).

- Prisoners: In the South African context, Pienaar (1989:10) has recently drawn attention to "the risk of infection to other prisoners and the threat of violence and intimidation towards infected individuals. Every person who is locked up has the right to be protected against sexual abuse in police station and prison cells".

It has been suggested that P.W.A.'s, especially gay men and intravenous drug abusers, belong to the Old Testament category of the "alien in the midst" (Shelp et al., 1986:1011). The Hebrew roots from which "alien" is derived are ger (sojourner), zer (stranger) and nakri (foreigner). These terms apply generally to non-Hebrews, usually living temporarily in Israel, who then came under the full protection of the law. Passages such as Exodus 22:21, 23:9; Leviticus 19:33; Deuteronomy 1:16; 10:18; 23:7; 24:14, Malachi 3:5 indicate that the alien had an unarguable claim on the community for compassionate assistance. This approach is continued in the New Testament generally, e.g. passages such as Matthew 24:31-46; Galatians 6:10 and especially the Gospel of Luke with its concern for the poor, the outcast and the dispossessed. Ogletree (1985:28) argues that hospitality to the stranger is applicable to the whole nature of the Christian moral life and includes at least two basic components: a willingness to protect and an openness to new understanding and experiences. This could lead to Christians seeking to protect and promote the rights of such "strangers". If "equitable justice" requires that persons be treated equally in similar situations, and "distributive justice" calls for the goods and services of society to be fairly shared among all, "compensatory justice", whereby special provisions is made for those having special needs, may demand that the extraordinary health care needs of P.W.A.'s are met (Vaux, 1985:910). It is therefore probable that this will have socio-political implications for Southern Africa in the near future.

\subsubsection{Private and public morality?}

A complicating factor in the A.I.D.S. crisis is that whereas the "strangers" in the Bible who are to be protected usually suffer for reasons entirely beyond their own control, A.I.D.S. spreads largely through well-defined behaviour patterns, rooted in chosen 
lifestyles. In Britain, the legalizing of homosexual acts between consenting adults in private (1967) was in part motivated by the Wolfenden Committee Report which drew a sharp distinction between public and private behaviour, which had already been clearly articulated in the famous tract of John Stuart Mill On Liberty in 1859. Dr. Caroline Collier (1987:64-65) comments: "The arrival of A.I.D.S. has set a large question mark beside that conclusion ... A.I.D.S. is very much a personal and public concern". Since what the individual does by way of risking the spread of A.I.D.S. has far-reaching consequences for others unknown to him or her, society is therefore forced to take responsibility for influencing individual behaviour. This is already happening in Southern Africa through various "public awareness" campaigns and media exposure, especially since 1988 .

\section{THE CHURCH'S PASTORAL RESPONSE}

The A.I.D.S. crisis does not only demand an adequate theological-ethical understanding by the church, but also appropriate pastoral responses. What are some of these?

\subsection{Corrective education - to remove the irrational response of fearful ignorance}

A.I.D.S. can be an emotive issue, generating more heat than light, therefore pulpit and pastoral ministry should be directed at helping congregations respond positively rather than merely react fearfully. The "myths" of possible transmisson by casual contact with P.W.A.'s such as the use of the common cup in the Lord's Supper or the spread of the virus in baptismal water should be dispelled by the conveying of medically accurate information, i.e. that the virus can only be spread by sexual contact, infected needles, transfusions of contaminated blood products and from infected mothers to their newborn (Pienaar, 1985:5-6).

\subsection{Preventative education - to encourage a monogamous lifestyle}

Dr. Andrew Taylor (1987:32), a medical practioner of Liverpool, England has asserted that "fidelity within marriage and chastity outside marriage would virtually dispose of the disease within one generation". Similarly, U.S. Surgeon General C. Everett Koop (1985:52) claims that "A.I.D.S. can be maintained at its approximate level today if people maintain mutually faithful, monogamous sexual relationships". Although some dislike such "moralizing", Koop (1985:52) responds: "What I have said about containing A.I.D.S. is a public health statement. But it is interpreted by people who don't 
like prohibition of a permissive sexual lifestyle as a moral statement". As Jesus responded to the custom of easy divorce (Mat. 19:3-9 based on Deut. 24:1-4) by going back to the "one-flesh" principle in Genesis 2:24, so the church must again assert this Christian ethical teaching as part of the Biblical doctrine of man. Thus Karl Barth found the essence of Imago Dei in the grace of man and woman being together for each other, their children and the world. Similarly, Kenneth Vaux (1985:911) comments: "Though infinite tenderness and understanding must always mark our friendship with those who, in freedom or tragic necessity, choose other styles of life, the congregation must nonetheless proclaim a normative vision of human sexuality - which is also a message of health - and above all it must display a profound humility, founded in our common frailty and dependence".

\subsection{Mission opportunities}

In Uganda, the "epicentre" of Africa's A.I.D.S. epidemic, a consortium of churches and Christian groups have distributed over 1000 Bibles and 80000 tracts as part of the Answer Project, the brainchild of dr. Richard W. Goodgame, a Southern Baptist mis sionary physician who teaches medicine at Makerete University Hospital in Kampala. The tract is distributed at seminars and presents medical facts about A.I.D.S. and how it is spread, examines Biblical teaching on sexuality and marriage, responsibility towards people who are suffering and how those dying of A.I.D.S. can have eternal life through Christ. Churches in Southern Africa also need to identify cities and areas with significant numbers of A.I.D.S. sufferers and respond redemptively.

\section{$2.4 \quad$ Ministry challenges}

There are at least three basic A.I.D.S.-related groups needing pastoral ministry.

\subsubsection{P.W.A.'s (Persons with A.I.D.S.)}

While patients suffering from other terminal diseases such as cancer can at least look forward to general public acceptance and compassionate care, P.W.A.'s face further crushing burdens such as suspicion, rejection, a sense of guilt, loneliness and crippling financial costs. In the United States, an entire church (the Universal Fellowship of Metropolitan Community Church) has been formed outside of mainstream Protestantism to care for those rejected because of sexual matters by more traditional denominations (Stiles, 1986:534). Some have switched denominational allegiances, while at least one nominal Christian has become a conservative Jew since "his new religion has 
helped him to feel a solidarity with and have compassion for any persecuted population. Because he believes that God sides with people who are treated unjustly, he should too" (Shelp et al.,1986:176).

A redemptive response to A.I.D.S. may be based on 1 John 4:18-21: "There is no fear in love. But perfect love drives out fear ... For anyone who does not love his brother, whom he has seen, cannot love God whom he has not seen". Where this fear is overcome, the gloom of the A.I.D.S. crisis is partly dispelled by a ray of light as illustrated in the following examples:

- over fifty couples respond to an appeal for adoptive parents for an infant infected with the A.I.D.S. virus (McGee, 1988:35);

- $\quad$ some have formed a meaningful relationship with God and with people which they may not otherwise have formed. "A.I.D.S., or any fatal disease reminds persons who have it that time, like life, is a precious possession. If they are to make sense of life, death, morality or God, they must do it promptly" (Shelp et al., 1986:182);

- until recently, dying and death were almost made invisible in the regular life of Western Christian communities. The A.I.D.S. pandemic has again brought the church back to the reality of dying and death in the midst of sophisticated, technological society. The gracious invitation of Jesus "I am the resurrection and the life. He who believes will live, even though he dies; and whoever believes in me will never die. Do you believe this?" (John 11:25-26) suddenly is not as "irrelevant" to modern man as has often been alleged;

- although this does not necessarily indicate a real "change of heart" arising from a desire to please God, the A.I.D.S. crisis has in some cases led to a positive change towards safer sexual practices, especially in the direction of monogamy; and

- a pastor reports that amongst the active members of his congregation today are some whose first contact with the church was through hospital visitation and a funeral service for an A.I.D.S. patient in the family (Schaper, 1986:27).

Ministry to P.W.A.'s is usually costly in terms of time since pastoral presence demands the time to be with people, unhurried by other concerns. P.W.A.'s in the terminal stages are often too weak to sit for a normal hour-long worship service and therefore have to be ministered to mainly at home or in hospital. In the light of Acts 6:2-4, "it would not be right for us to neglect the ministry of the word of God in order to wait on tables ...", this will probably need to be a specialized ministry either of other suitable members of congregations who are not "full-time" pastors with the responsibility of preparing two new sermons and a Bible study each week, or a pastor from a large congregation with several pastors, who is largely free from regular preaching and pastoral responsibilities. 
Specific ministries that may be offered by the congregation to P.W.A.'s include visits in person and by telephone, transportation to hospital or clinic, provision of meals, shopping, housekeeping, housing, financial subsidies, sitting and basic nursing care, efforts at reconciliation and support as a patient dies. No person, "gay" or "straight", should face practically alone what P.W.A.'s have to face.

\subsubsection{Families and friends of P.W.A.'s}

In "Pattern One" communities, where A.I.D.S. has spread largely among homosexual and bisexual men and drug abusers, many families of P.W.A.'s are desperately afraid of the stigma involved should it become known that their son is "gay" and has A.I.D.S. Without in any way condoning the promiscuity that may or may not be involved in particular cases, pastors and congregations must not abandon such families in their hour of need. It should not be necessary for such families to attempt a "cover-up operation" and try to give the impression that their son has "tuberculosis" or "cancer". Similarly a couple whose son died of A.I.D.S. urged other such parents: "Whatever you do, stand by your children. Do not shun them. Let your children know you love them" (Shelp et al., 1986:139).

One of the most complicated ethical aspects in this area of ministry is when a chaplain or counsellor is caught between the needs of the patient's family and those of the patient's lover or gay friends. Homosexual relationships are not recognised in law and unless the patient has arranged otherwise, the patient's family have legal authority to make decisions concerning the patient's care, funeral arrangements etc. if he or she becomes unable to make decisions. Advisor to hospital chaplains John Bohne (1986:187) warns against the tendency to automatically side with the "legitimate" family at the expense of ministry to the "illegitimate" family. Often the financial and practical burdens of caring for P.W.A.'s falls to the healthy partner who may face a long cycle of regular working hours followed by the additional demands of feeding, bathing and medicating the patient.

In "Pattern Two" communities (including many African countries) A.I.D.S. is transmitted largely by heterosexual contacts and so there will be more men and women becoming widows, thus disrupting family life and multiplying the numbers of single-parent families needing pastoral ministry and care. 


\subsubsection{Professional care-providers}

Doctors, nurses and other medical personnel who care professionally for A.I.D.S. patients also need specialized pastoral ministry. They are "burned-out people looking to other burned-out people for support" (Shelp et al, 1986:155), since P.W.A.'s often have several major illnesses at once requiring multiple treatments and an increased amount of staff time to implement them. Because their caring ministries ultimately seem to "fail" through the death of their patients, these professionals can be not only physically drained, but also have their emotional balance upset and religious beliefs challenged as a result of their work. Some have eventually stopped attending worship because they felt both pastor and congregation were out of touch with some of the harsh realities of life as they experienced it. This has even led to anger and a strangely self-righteous and hyper-critical attitude towards ordinary church people who do not yet display the sensitivity and compassion towards particular groups of people that such professionals have themselves gained because of their experience in A.I.D.S.-related ministries. Clearly the vital role of professional care-providers in the A.I.D.S. crisis should be recognised by the church and responded to through appropriate pastoral ministry.

\section{CONCLUSION}

The church cannot simply ignore the A.I.D.S. crisis and, like the Levite in Luke 19:32, "pass by on the other side". Pastors and congregations need to consider the Biblical and theological issues involved and respond - through corrective and preventative pulpit education and compassionate pastoral care for those in their communities who either now or in future may be affected by the A.I.D.S. crisis.

\section{BIBLIOGRAPHY}

BOHNE, J. 1986. AIDS: Ministry Issues for Chaplains. Pastoral Psychology, 34(3):173-192, Spring. CARAcL, M. 1988. AIDS in the World. Global Program on AIDS of the World Health Organization. Lutheran World Federation Documentation: 14-22, Sept.

COLLIER, C. 1987. The Twentieth Century Plague. Reading : Lion Publishing.

CRANFIELD, C.E.B. 1975. International Critical Commentary on Romans. Vol 1. Edinburgh : T \& T Clark.

FRAME, R. 1985. The Church's Response to AIDS - Is compassion waning in light of a so-called gay disease? Christianity Today, 29(17):50-51, Nov. 22.

HANCOCK, L. 1985. Fear and Healing in the AIDS Crisis. Christianity and Crisis, 45:225-258, June 24. KOOP, C.E. 1985. Addressing the AIDS Threat. Christianity Today, 29(17):52, Nov. 22.

McGEE, P. 1988. Discrimination, Guilt and Fear. Lutheran World Federation Documentation: 32-39, Sept. 
MUMPER, S.E. 1988. Missionaries and Christians in Uganda meet Questions of AIDS Crisis with Answer Project. Baptists Today: 8, Nov.

OGLETREE, T.W. 1985. Hospitality to the Stranger. Philadelphia : Fortress Press.

PIENAAR, PJJ. 1989. AIDS and the Criminal Justice Officer. University of Fort Hare : Department of Criminology.

QUERE, R. W. 1987. The AIDS Crisis, A Call to Mission Based on 1 Peter. Currents in Theology and Mission, 14(5):361-369

SCHAPER, R.L. 1988. The AIDS Epidemic: A Pastor's Expericnce Lutheran World Federation Documentation: $23-29$, Sept.

SHEI.P, E.E., SUNDERI.AND, R.H. \& MANSELL, WA. 1986. A]nS.Personal Stories in Pastoral Perspective. New York: Pilgrim Press.

SHOEMAKER, HS. 1986. God as Judge, God as Saviour. The Christion Ministry, 17(1): 24-26, Jan.

STILES, BJ. 1986. AIDS and the Churches - Belated, Growing Response. Christianity and Crisis, 45(22): 534-536, Jan. 13.

TAYLOR, A. 1987. The Scourge of AIDS. Reformation Today, (96):30-32, March - A pril.

VAUX, K. 1985. AIDS as Crisis and Opportunity. Christion Century, (102): 910-911, Oct.

WAKEFIELD, M. 1989. AIDS Warning at P.E. Pensions Conference. Eastem Province Herald. March 21. 